19 Brodmann K. Vergleichende Lokalisationslehre der Grosshirnrinde in ihren Principien, dargestellt auf grund des Zellenbaues [Comparative Localisation Evidence for the Cortex, Explained and Depicted by Cell Structure] (2nd edn). Johann Ambrosius Barth Verlag, 1925.

20 Brett M, Johnsrude IS, Owen AM. The problem of functional localization in the human brain. Nat Rev Neurosci 2002; 3: 243-9.

21 Ashburner J, Friston KJ. Unified segmentation. Neuroimage 2005; 26: 839-51.

22 Pochon JB, Levy R, Fossati P, Lehericy S, Poline JB, Pillon B, Le Bihan D, Dubois $B$. The neural system that bridges reward and cognition in humans: an fMRI study. Proc Natl Acad Sci USA 2002; 99: 5669-74.

23 Mottaghy FM, Willmes K, Horwitz B, Mueller HW, Krause BJ, Sturm WJ. Systems level modeling of a neuronal network subserving intrinsic alertness. Neuroimage 2006; 29: 225-33.

24 Bush G, Luu P, Posner Ml. Cognitive and emotional influences in anterior cingulate cortex. Trends Cogn Sci 2000; 4: 215-22.

25 Bloom JS, Hynd GW. The role of the corpus callosum in interhemispheric transfer of information: excitation or inhibition? Neurpsychol Rev 2005; 15: 59-71.

26 Rogers RD, Ramnani N, Mackay C, Wilson JL, Jezzard P, Carter CS, Smith SM Distinct portions of anterior cingulate cortex and medial prefrontal cortex are activated by reward processing in separable phases of decision-making cognition. Biol Psychiatry 2004; 15: 594-602.

27 Kirsch P, Schienle A, Stark R, Sammer G, Blecker C, Walter B, Ott U, Burkart $J$, Vaitl D. Anticipation of reward in a nonaversive differential conditioning paradigm and the brain reward system: an event-related fMRI study. Neuroimage 2003; 20: 1086-95.

28 Ohnishi $T$, Matsuda $H$, Hashimoto $T$, Kunihiro $T$, Nishikawa $M$, Uema $T$, Sasak M. Abnormal regional cerebral blood flow in childhood autism. Brain 2000; 123: $1838-44$.

29 Happé F, Ehlers S, Fletcher $\mathrm{P}$, Frith $\mathrm{U}$, Johansson $\mathrm{M}$, Gillberg C, Dolan R, Frackowiak R, Frith $\mathrm{C}$. 'Theory of mind' in the brain. Evidence from a PET scan study of Asperger syndrome. Neuroreport 1996; 8: 197-201.

30 Luna B, Minshew NJ, Garver KE, Lazar NA, Thulborn KR, Eddy WF, Sweeney JA. Neocortical system abnormalities in autism: an fMRI study of spatia working memory. Neurology 2002; 59: 834-40.

31 Waiter GD, Williams JH, Murray AD, Gilchrist A, Perrett DI, Whiten A. Structural white matter deficits in high-functioning individuals with autistic spectrum disorder: a voxel-based investigation. Neuroimage 2005; 24: 455-61.
32 Allman JM, Watson KK, Tetreault NA, Hakeem AY. Intuition and autism: a possible role for Von Economo neurons. Trends Cogn Sci 2005; 9: 367-73.

33 Murphy DG, Daly E, Schmitz N, Toal F, Murphy K, Curran S, Erlandsson K, Eersels J, Kerwin R, Ell P, Travis M. Cortical serotonin 5-HT2A receptor binding and social communication in adults with Asperger's syndrome: an in vivo SPECT study. Am J Psychiatry 2006; 163: 934-6.

34 Haznedar MM, Buchsbaum MS, Hazlett EA, LiCalzi EM, Cartwright C, Hollander E. Volumetric analysis and three-dimensional glucose metabolic mapping of the striatum and thalamus in patients with autism spectrum disorders. Am J Psychiatry 2006; 163: 1252-63.

35 Haznedar MM, Buchsbaum MS, Metzger M, Solimando A, Spiegel-Cohen J, Hollander E. Anterior cingulate gyrus volume and glucose metabolism in autistic disorder. Am J Psychiatry 1997; 154: 1047-50.

36 Delgado MR, Labouliere CD, Phelps EA. Fear of losing money? Aversive conditioning with secondary reinforcers. Soc Cogn Affect Neurosci 2006; 1 : 250-9.

37 Chung MK, Dalton KM, Alexander AL, Davidson RJ. Less white matter concentration in autism: 2D voxel-based morphometry. Neuroimage 2004; 23: $242-51$.

38 Schmitz N, Rubia K, Daly E, Smith A, Williams S, Murphy DG. Neural correlates of executive function in autistic spectrum disorders. Biol Psychiatry 2006; 59: 7-16.

39 Sowell ER, Thompson PM, Holmes CJ, Jernigan TL, Toga AW. In vivo evidence for post-adolescent brain maturation in frontal and striatal regions. Nat Neurosci 1999; 2: 859-61.

40 Paus T, Koski L, Caramanos Z, Westbury C. Regional differences in the effects of task difficulty and motor output on blood flow response in the human anterior cingulate cortex: a review of 107 PET activation studies. Neuroreport 1998: 9: R37-R47.

41 Baron-Cohen S, Ring HA, Wheelwright S, Bullmore ET, Brammer MJ, Simmons A, Williams SC. Social intelligence in the normal and autistic brain: an fMRI study. Eur J Neurosci 1999; 11: 1891-8.

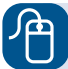

\title{
The adult I may have become
}

\section{Sarah Swainston}

I sometimes wonder who I would have been if I had not become mentally ill. At seventeen I was head girl at school, doing well in my A-level course and on target for entry to medical school. From eighteen to twenty I was a medical student, doing reasonably well and enjoying life. At the age of twenty-one, I suddenly and unexpectedly crashed into a depression that lasted several months and required ECT even to begin to lift it. At twenty-two I returned to medical school better, but a different person. Once you have looked into that black empty hole, the memories never quite fade.

But I was young, on the whole optimistic and assumed that my life would continue on its previously smooth road. I knew that I had lost contact with some of my friends but it never occurred to me that I might have lost contact in a way with my previous self.

Over twenty years later and following several more episodes, it has finally dawned on me that I have never grieved for that lost twenty-one-year-old. It was brought home to me by a film Shine, which is about a brilliant young pianist whose future is suddenly shattered by a devastating psychiatric illness. I found myself crying for him - for whom he could have been, what he could have done, the relationships he missed - and I thought, 'what about me?' I've been much luckier. I've got a family, a career and a husband. But, I still wonder - how would I have been different if I had never been ill?

When someone loses a leg we understand the loss; when a couple has a disabled child, we recognise that they need time to grieve for the other child they never had. When working with an adolescent with a chronic illness we try and help them come to terms with the fact that they may never have a future. But when working with a young person with mental illness, do you ever think of it in terms of the loss of the adult they could have become? 